\title{
Muscle regeneration through therapy with estromal stem cells in injury of infraespinhosus muscle of sheep ${ }^{1}$
}

Aline Grama Moreira Brandão', Angélica Consalter', Juliana da Silva Leite", Helia Zamprogno'", Ana Maria Reis Ferreiralv

'MSc, Veterinarian, Postgraduate Program in Veterinary Medicine (Animal Clinic and Reproduction), Universidade Federal Fluminense (UFF), Niteroi-RJ, Brazil. Intellectual and scientific content of the study, manuscript writing, critical revision. "PhD, Full Professor, Department of Pathology and Veterinary Clinic, UFF, Niteroi-RJ, Brazil. Scientific content of the study, technical procedures, critical revision.

IIIPhD, Veterinarian, Bulington Emergency and Veterinary Specialists, Williston, United States. Intellectual and scientific content of the study, critical revision.

IVPhD, Full Professor, Department of Pathology and Veterinary Clinic, UFF, Niteroi-RJ, Brazil. Scientific content of the study, technical procedures, critical revision.

\begin{abstract}
Purpose: To evaluate the effects of rotator cuff muscle regeneration in sheep and establish an experimental model for the use of autologous stem cells as a treatment option for tendon injuries.

Methods: Infrared muscle tenotomies and Penrose drain implantation were performed on 12 shoulders of six clinically healthy adult sheep. After 60 days, the tendons were submitted to tissue repair, drainage removal, and divided into two groups according to the use of autologous stromal stem cells for treatment. Muscle regeneration was performed by biopsy on days 14 and 34 after repair.

Results: The treatment group with cell therapy showed neovascularization and expressive regeneration. Complete regeneration of the muscle pattern did not occur in any sample although some muscle gain was obtained in the group 1 samples at 34 days after repair and introduction of stem cells. Fatty infiltration of these samples from group 1 at 34 days was less intense than that in samples from group 2 at 34 days after repair without the introduction of autologous precursor cells.

Conclusion: The sheep proved to be a good experimental model to assist in the development of research on muscle regeneration and the autologous manipulation of stem cells as a therapeutic option.
\end{abstract}

Key words: Muscles. Regeneration. Stem Cells. Models, Animal. Sheep. 


\section{Introduction}

The rupture of tendons of shoulder muscles may be responsible for the muscular degeneration that has been affecting a large part of the human population. In histopathological analysis, this condition is characterized by the infiltration of fat cells into muscle tissue ${ }^{1}$.

The most important consequence of degeneration is loss of muscle function and range of motion, leading to functional and structural changes in skeletal muscles. Preliminary studies have shown that degeneration may involve all muscles that have tendon rupture ${ }^{1-4}$

Fatty degeneration is an important prognostic factor for rotator cuff surgeries ${ }^{3}$ muscle denervation and tendon tear. Whereas after nerve injury muscle atrophies in the denervated area, the distribution of muscle atrophy following tear of its tendon is not known. Standardized MRI scans of 64 consecutive, painful shoulders were evaluated for supraspinatus tendon tearing, myotendinous retraction, supraspinatus muscle atrophy, fatty infiltration, ratio of the scapular (deep. This condition is progressive over time and accompanied with a weakness of muscle function, although it diminishes after repair; moreover, it is a factor that predicts repairability of the tendon and substantially influences the clinical outcome of surgical intervention ${ }^{13,5,6}$

Given the hypocellularity and hypovascularisation of tendon tissues, the natural healing potential is extremely low and inefficient, with significant dysfunction and disability. The application of stem cells can considerably improve the repair of tendon ruptures ${ }^{7}$.

The study of stem cells is based on cell differentiation that occurs in embryos, where different tissues are generated from a single cell. We can also find discrete populations of stem cells in the bone marrow, muscle, circulating sage, and brain, which promote the renewal of cells that have been lost by natural wear, injury, or disease ${ }^{8}$.

The present study aimed to evaluate rotator cuff muscle degeneration in sheep and establish an experimental model for the use of autologous stem cells as a treatment option for tendon injuries.

\section{Methods}

This work was evaluated and approved by the Animal Use Ethics Committee, Universidade Federal Fluminense (protocol no. 089/06).

\section{Experimental groups}

Six clinically healthy female sheep of the Santa Inês breed (aged 2 to 4 years with an average weight of $30 \mathrm{~kg}$ ) were used. The left and right shoulders of the sheep were used and a total of 12 shoulders were obtained. To simplify understanding of the study, the shoulders are referred to and not the individual sheep. Tenotomies of the infraspinatus muscle and suture of the "Penrose" drain were performed to avoid regeneration. The shoulders were divided into two groups. Figure 1 shows an explanatory scheme of the experimental procedure.

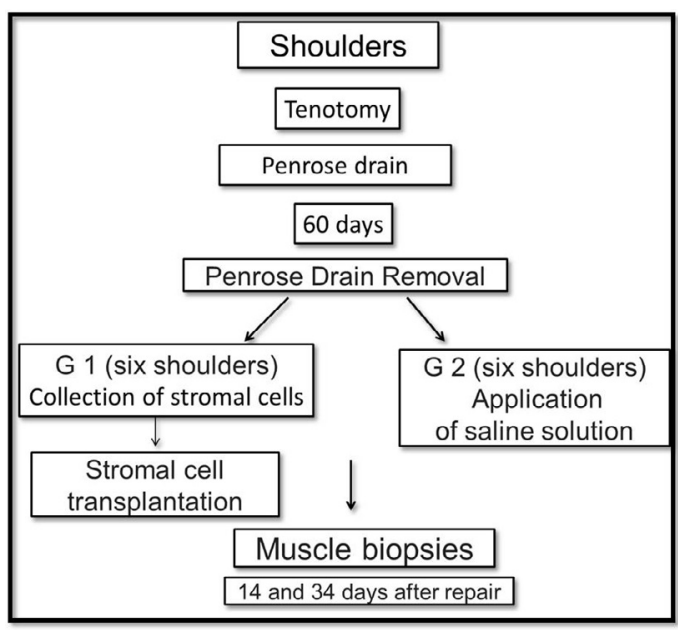

Figure 1 - Schematic of the experimental procedure in sheep. 
Group 1 was composed of six shoulders of different animals that underwent tenotomies and suture of a "Penrose" drain and then underwent a new surgical procedure after 60 days post-injury for drainage removal and collection of stromal cells of the medulla (Figure 2). After quantification and expansion, the cells were transplanted at the site of tendon injury the day after this procedure. Muscle biopsies were performed 14 days after the repair (74 days after injury) on three shoulders and at 34 days after repair (94 days after injury) on the other three shoulders.

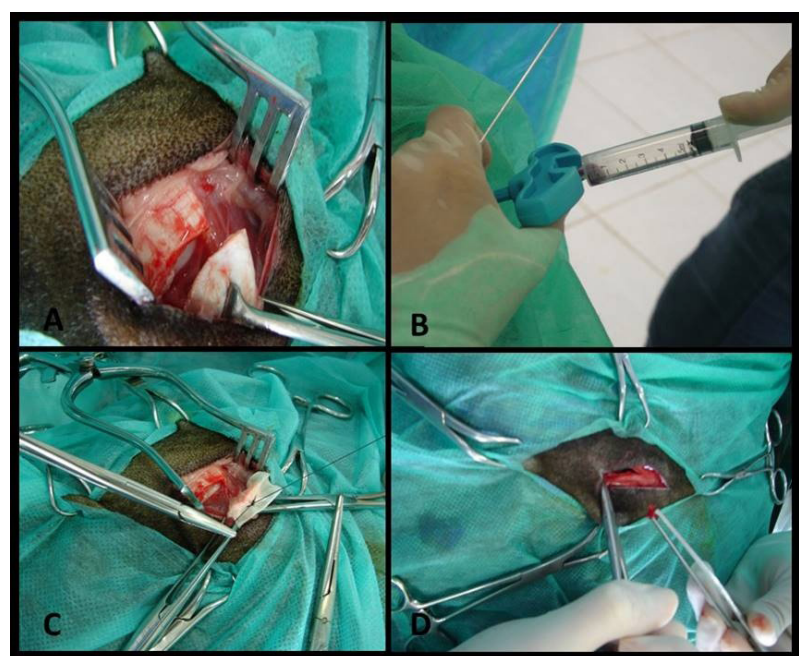

Figure 2 - Photomicrography of the infraspinatus ovine muscle. A: tenotomy of the infraspinatus of sheep. B: suture of the penrose drain in the tendon of the infraspinatus muscle. C: Collection of the medullary aspirate for the isolation of stem cells. $\mathbf{D}$ : collection of biopsies.

Group 2 was composed of six shoulders of different animals that underwent tenotomies and suture of a "Penrose" drain and then submitted to a new surgical procedure for the drainage and the application of saline solution after 60 days post-injury. Moreover, muscle biopsies were performed at 14 days ( 74 days after injury) on 3 shoulders and at 34 days ( 94 days after injury) on 3 other shoulders.

\section{Surgical technique}

The animals were pre-medicated with ketamine hydrochloride (Vetnil ${ }^{\circ}$, Louveira-SP, Brazil) at the dose of $10 \mathrm{mg} / \mathrm{kg}$ intramuscularly, intubated, and induced with $1 \%$ propofol (2-4 $\mathrm{mg} / \mathrm{kg}$ ) intravenously. Anesthetic maintenance was performed using $1 \%$ isoflurane. On the day of the surgical procedure and on the first three postoperative days, $4 \mathrm{mg} / \mathrm{kg}$ carprofen (Zoetes ${ }^{\circ}$, Benfica-RJ, Brazil) was administered for analgesia. Antibiotic therapy with 14,400 $\mathrm{IU} / \mathrm{kg}$ penicillin, $6 \mathrm{~g} / \mathrm{kg}$ streptomycin, and dihydrostreptomycin (Zoetes ${ }^{\circ}$, Benfica-RJ, Brazil) was conducted intramuscularly once every 5 days. All surgical procedures were performed with wide tricotomy and routine aseptic and antisepsis procedures under the effect of general anesthesia.

\section{Histopathological analysis of biopsies}

After removal of the drain, "Penrose" biopsies were performed in groups 1 and 2 at with 74 and 94 days post-injury, respectively. The collected samples were fixed in $10 \%$ formalin and processed in paraffin by the usual histological techniques for hematoxylin and eosin.

To evaluate fatty infiltration, we established groups varying from stage 0 to stage 5 , in which the samples in stage 0 presented with normal morphology. In the stage 1 samples, we noticed a discrete fat infiltration that occurred only in the perimysium. By contrast, the samples in stage 2 presented a fatty infiltration in the perimysium and a discrete fat infiltration in the endomysium. Stage 3 was characterized by moderate infiltration both in the endomysium and perimysium. In stage 4, infiltration occurred in both leaflets, but it was considered intense only in the perimysium. Finally, at stage 5 , fatty infiltration occurred intensely in both the endomysium and perimysium. 


\section{- Results}

Post-surgical recovery

The animals exhibited good postsurgical recovery. They remained in their stations, walked immediately after the procedure, and presented slight claudication only at gallop.

\section{Histopathological analysis of biopsies}

In the gurpo1, after 14 days of the surgical procedure of repair of the tendon and implantation of stem cells, the performed biopsies demonstrated an inflammatory infiltrate that varied from discrete to accentuated, multifocal to perivascular, and with the presence of mononucleated cells. Fatty infiltration was characterized in grade 4 with moderate presence of fat tissue both in the endomysium and perimysium (Figure 3). Areas of hemorrhages were observed at the borders in some samples with necrosis and fibrosis. A decrease in fiber size was noted in some samples, and hyaline degeneration was found in others. Neovascularization was observed in adipose tissue and tendinous tissue in one of the samples.

Samples collected at 34 days after surgical repair of the tendon and implantation of stem cells demonstrated decreased fatty infiltration at grade 1 , that is, in the injured area (Figure 3 ). The presence of satellite cells and a discrete moderate infiltrate of mononuclear cells were observed. Bleeding was evidenced in several areas with fibrosis and necrosis. The fiber arrangements were disorganized, somewhat diminished in size, and atrophied. Discrete fibrosis may also be observed in the endomysium and perimysium. These samples exhibited tendinous tissue, and neovascularization and scarce mixed inflammatory infiltrate were observed.

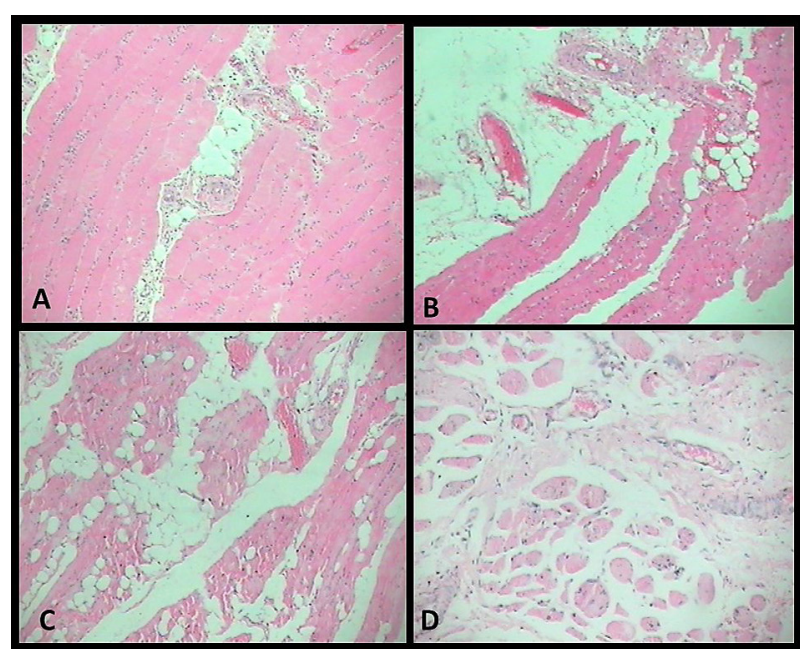

Figure 3-Photomicrography of the histopathological analysis from the infraspinatus muscle of sheep. $\mathbf{A}$ : grade 1 of a fat infiltrate increasing $\times 200(\mathrm{HE}), \mathbf{B}$ : grade 1 of a fat infiltrate increasing by $\times 200$ (HE). C: grade 4 of greasy infiltrate increasing by $x 200(\mathrm{HE})$. D: grade 4 of greasy infiltrate increasing by $x 400$ (HE).

In group 2, at 14 days after the repair, the collected samples showed grade 5 of fatty infiltration, with intense presence of endomysial and perimysium fat tissue in all the samples and neovascularization in several areas, including the adipose tissue itself. The inflammatory infiltrate, in turn, was diffuse, ranging from discrete to moderate with presence of mononuclear and mixed infiltrate. Hemorrhagic areas were evidenced at different sites in the samples, as well as necrosis and fibrosis of muscle fibers that were disorganized and with decreased size, thereby indicating atrophy. Hyaline degeneration occurred in all samples of this period, and hemoglobin pigments were not observed in the samples. The presence of tendinous tissue was observed in all samples.

A discrete to moderate inflammatory infiltrate with presence of mononuclear cells with hemorrhages at the borders and in several areas of the samples was observed in the samples collected 34 days after the repair, 
without the use of stem cells. Fatty infiltration was characterized between grades 4 and 5 with the presence of adipose tissue in both the endomysium and perimysium of all samples. The muscle fibers were disorganized, with intense necrosis. The presence of tendinous tissue was evidenced in two samples, in which neovascularization, hemorrhage, and mixed inflammatory infiltrate scarce or absent were observed.

\section{Discussion}

The use of sheep as an experimental model for muscular injuries is scarce in the literature. The results observed in this study demonstrated that the response to the lesion developed by sheep was more similar to that described in human studies than in rabbits ${ }^{1,9-11}$ Thus, sheep are good experimental models for the evaluation of muscle injury.

The ewes underwent a complete rupture in the insertion of the tendon of the infraspinatus muscle to develop fatty degeneration because of the disuse and denervation provoked in this muscle. This choice of tendon was based on ${ }^{1}$ who described that rupture of tendon degeneration does not regress even after repair and may even increase. The use of the "Penrose" drain was incorporated into the protocol to prevent adherence and subsequent muscle regeneration.

The major consequences of disuse, caused by the degeneration or deprivation of the muscle, depend on the thickness of the tendon and the time of evolution of this lesion ${ }^{12}$. According to Terra and coworkers ${ }^{13}$, the earlier the repair is performed, the later complications will be less than $20 \%$. The data obtained in the present experiment reveal that degeneration is already well established in a relatively short time of 60 days after tendon rupture. In spite of the development of degeneration and total rupture of the tendon of the infraspinatus muscle, the animals were clinically normal. They demonstrated only weak claudication at the gallop and pain palpation of the incised area only in the first postoperative days, and some stopped feeding or became apathetic.

Joint and muscle problems are common in humans, and the shoulder is the joint of greater mobility and instability of the human body; therefore, the shoulder is prone to dislocations ${ }^{14}$. Muscle mass changes and degeneration processes can lead to tendon rupture, loss of movement, and much pain. The loss of the capacity to develop tension of the muscles that suffered injury promoted degeneration by disuse. Rotator cuff lesions are a significant source of shoulder pain in humans, and they occur mainly in patients between $\mathbf{4 0}$ and 60 years of age and may be traumatic or of degenerative origin ${ }^{15}$.

Classification based solely on histopathological findings is difficult to apply clinically; another symptom-based classification that divides tendinopathies into mild, moderate, and severe seems to be more enlightening ${ }^{16}$. In the histopathological analysis of the muscular samples of this study, the presence of muscular degeneration was observed even after tenorrhaphy. In a symptomatic analysis, we observed that the animals presented clinically well, with light claudication only in the gallop.

According to previous studies ${ }^{1,2,5}$, the indication of repair of the rotator cuff tendon should be performed as soon as possible, because the time between diagnosis and surgical repair is what determines the success of the regeneration. In this study, complete regeneration of the muscle pattern did not occur in any sample although some muscle gain was obtained in the group 1 samples at 34 days after repair and introduction of stem cells. Fatty infiltration of these samples from group 1 at 34 days was less intense than that in samples 
from group 2 at 34 days after repair without the introduction of autologous precursor cells.

The inflammatory infiltrate, ranging from mild to moderate, was present in all muscle samples. What is in agreement with the findings of in which it identified in animals the presence of inflammatory cells in the tendon posterior to the surgical section of the same ${ }^{17}$. The absence of inflammatory cells were reported in lesions caused by ruptures of the rotator cuff tendons, short radial extensor carpal, patellar, and Achilles in humans, different from the results observed in this study ${ }^{10}$. However, Fávaro et al. ${ }^{17}$ obtained good results at 2 and 4 weeks after the implantation of stem cells that promoted the remodeling of the tendon in the early stages of cicatrization.

The presence of satellite cells in the muscular interstitium should be considered according to Fávaro et al. ${ }^{17}$; once preserved, these cells play an important role in muscle regeneration and restoration of functions previously developed by the musculature. In this way, they can reverse the greasy degeneration and provide the development of new muscle cells. After tendon rupture, these satellite cells may not be conserved, so the use of cell therapy with autologous bone marrow stem cell implant associated with the repair may be important, because these cells play a role similar to satellite cells ${ }^{17,18}$.

\section{Conclusions}

The experimental model used was adequate for the study of the fatty infiltration of rotator cuff muscle tissue. Moreover, the use of autologous stem cells as a treatment option was reasonable. Cell therapy repair through autologous bone marrow stem cell implantation at the lesion site represented reinforcement for muscle regeneration.

\section{References}

1. Goutallier D, Postel JM, Bernageau J, Lavau $L$, Voisin MC. Fatty muscle degeneration in cuff ruptures. Pre- and postoperative evaluation by CT scan. Clin Orthop Relat Res. 1994 Jul;(304):78-83. PMID: 8020238.

2. Jost B, Pfirrmann CW, Gerber C, Switzerland Z. Clinical outcome after structural failure of rotator cuff repairs. J Bone Joint Surg Am. 2000 Mar;82(3):304-14. PMID: 10724223.

3. Meyer DC, Pirkl C, Pfirrmann CWA, Zanetti $\mathrm{M}$, Gerber C. Asymmetric atrophy of the supraspinatus muscle following tendon tear. J Orthop Res. 2005 Mar;23(2):254-8. doi: 10.1016/j.orthres.2004.06.010.

4. Mori K, Chano T, Matsumoto K, Ishizawa $M$, Matsusue $Y$, Okabe $H$. Type-selective muscular degeneration promotes infiltrative growth of intramuscular lipoma. BMC Musculoskelet Disord. 2004 Jun;5:20. doi: 10.1186/1471-2474-5-20

5. Gerber C, Meyer DC, Schneeberger AG, Hoppeler $H$, von Rechenberg B. Effect of tendon release and delayed repair on the structure of the muscles of the rotator cuff: an experimental study in sheep. J Bone Joint Surg Am. 2004 Sept;86-A(9):1973-82. PMID: 15342760.

6. Godinho GG, França F de O, Freitas JMA, Santos FML e, Resende DS, Wageck JPZ, Fortes S,BP. Avaliação funcional em longo prazo do tratamento videoartroscópico das lesões parciais do manguito rotador. Rev Bras Ortop. 2015 Mar;50(2):200-5. doi: 10.1016/j.rbo.2014.03.005.

7. Hsieh C-F, Alberton $P$, Loffredo-Verde E, Volkmer E, Pietschmann M, Müller $P E$, Schieker $M$, Docheva D. Periodontal ligament cells as alternative source for cellbased therapy of tendon injuries: in vivo study of full-size Achilles tendon defect in a rat model. Eur Cell Mater. 2016 Oct;32:22840. doi: 10.22203/eCM.v032a15.

8. Bernardo JO, Escodro PB, Notomi MK, Roveri EG, Nascimento TG do. Coleta de células progenitoras periféricas por aférese automatizada em equino: relato de procedimento. Arq Bras Med Vete Zootecnia. 2017 Feb;69(1):259-63. doi: 10.1590/16784162-9124.

9. Godinho GG, Júnior P, Correa S, Schio C, 
Filho A, Souza J de, França, F.O, Freitas, JMA. Estudo da vascularização das bordas das lesões nas roturas completas do manguito rotador. Rev Bras Ortop. 2007 Jun;42(6):169-72.

10.Khan KM, Cook JL, Taunton JE, Bonar F. Overuse tendinosis, not tendinitis part 1: a new paradigm for a difficult clinical problem. Phys Sportsmed. 2000 May;28(5):38-48. doi: 10.3810/psm.2000.05.890.

11.Storti TM, Paniago AF, Faria RSS. Reparo de ruptura bilateral simultânea do bíceps distal: relato de caso. Rev Bras Ortop. 2017 Jan;52(1):107-10. doi: 10.1016/j. rbo.2016.02.008.

12.Ryan AS, Dobrovolny CL, Smith GV, Silver KH, Macko RF. Hemiparetic muscle atrophy and increased intramuscular fat in stroke patients. Arch Phys Med Rehabil. 2002 Dec;83(12):1703-7. doi: 10.1053/ apmr.2002.36399.

13.Terra BB, Rodrigues LM, Lima ALM, Cabral BC, Cavatte JM, De Nadai A. Reparo direto das lesões distais crônicas do tendão bicipital. Rev Bras Ortop. 2016 May;51(3):303-12. doi: 10.1016/j.rbo.2015.06.007.

14.Bahk M, Keyurapan E, Tasaki A, Sauers EL, McFarland EG. Laxity testing of the shoulder: a review. Am J Sports Med. 2007 Jan;35(1):131-44. PMID: 17130247.

15.Vieira FA, Olawa PJ, Belangero PS, Arliani $G G$, Figueiredo EA, Ejnisman B. Rotator cuff injuries: current perspectives and trends for treatment and rehabilitation. Rev Bras Ortop. 2015 Oct;50(6):647-51. doi: 10.1016/j.rboe.2015.10.012.

16.el Hawary R, Stanish WD, Curwin SL. Rehabilitation of tendon injuries in sport. Sports Med. 1997 Nov;24(5):347-58. PMID: 9368280.

17.Fávaro RC, Arruda A de O, Vialle LRG, Vialle EN.Influência daterapia celularmononuclear sobre a degeneração discal em coelhos. Rev Bras Ortop. 2016 Nov;51(6):707-15. doi: 10.1016/j.rboe.2016.10.003.

18. Seale $P$, Rudnicki MA. A new look at the origin, function, and "stem-cell" status of muscle satellite cells. Dev Biol. 2000 Feb;218(2):115-24. doi: 10.1006/ dbio.1999.9565.

\section{Correspondence:}

Angélica Consalter

Programa de Pós-graduação em Clínica e Reprodução Animal

Universidade Federal Fluminense

Rua Vital Brazil Filho, 64

24230-340 Niterói - RJ Brasil

angelicaconsalter@hotmail.com

Received: Nov 10, 2017

Review: Jan 11, 2018

Accepted: Feb 12, 2018
Conflict of interest: none

Financial source: none
${ }^{1}$ Research performed at Department of Pathology and Veterinary Clinic, Universidade Federal Fluminense (UFF), Niteroi-RJ, Brazil. Part of PhD degree thesis, Postgraduate Program in Veterinary Medicine (Animal Clinic and Reproduction). Tutor: Profa. Dra. Ana Maria Reis Ferreira. 